UDC 378.147:811.111'233

DOI https://doi.org/10.24919/2308-4863/39-3-31

Viktoriia SLABOUZ,

orcid.org/0000-0003-1810-4054

Candidate of Philological Sciences, Associate Professor, Associate Professor at the Department of Foreign Languages

Donbas State Pedagogical University

(Sloviansk,Donetsk region,Ukraine) queen_viktoiya28@ukr.net

Nataliia NIKITINA,

orcid.org/0000-0002-0653-7453

Candidate of Pedagogical Sciences, Associate Professor, Associate Professor at the Department of Foreign Languages

Donbas State Pedagogical University

(Sloviansk, Donetsk region,_Ukraine) nikitina_sdpu@ukr.net

\title{
PRINCIPLES OF USING MULTIMEDIA TEACHING AIDS IN PROFESSIONAL FOREIGN LANGUAGE TRAINING OF FUTURE PHILOLOGISTS
}

The article deals with the analysis of the principles of using multimedia teaching aids in professional foreign language training of future philologists. Ukraine's integration into the world community demands to optimize the system of humanitarian education. Such optimization is possible only on condition of introducing multimedia technologies into the educational process. The process of integration in the European educational space stimulates the professional interest of individuals in learning foreign languages as a means of communication, expanding international relations, trying to establish new standards of relations between the countries of the European Union. The study presented is relevant and urgent as the results of monitoring students' academic achievements have shown that the level of their foreign language training does not fully meet the requirements of the curriculum, and there is a need to find new ways to organize the learning process, as traditional forms, methods, and means do not meet modern trends to a sufficient extent and are not always able to ensure the advanced nature of professional education. The purpose of the article is to substantiate theoretically the content of the principles of using the multimedia teaching aids in professional foreign language training of future philologists. These principles are: the principle of compliance with the needs of society; the principle of taking into account the interests and professional needs of students-philologists; the principle of modeling the professional activities of future philologists; the principle of the communicative orientation of professional foreign language training of future philologists; the principle of visualization; the principle of the integrated use of multimedia teaching aids; the principle of positive emotionality; the principle of observance of ergonomic norms. Introducing these principles in the educational process, which is focused on the formation of professional foreign language competence of future philologists, requires modeling and technologicalization of this process in higher school.

Key words: multimedia teaching aids, multimedia technology, principle, professional foreign language competence, professional foreign language training.

Вікторія СЛАБОУЗ, orcid.org/0000-0003-1810-4054 кандидат філологічних наук, доиент, дочент кафедри іноземних мов

Донбаського державного педагогічного університету (Слов’янськ, Донецька область, Україна) quеen_viktoiya28@ukr.net

Наталія НІКІТІНА, orcid.org/0000-0002-0653-7453 кандидат педагогічних наук, доцент, дочент кафедри іноземних мов

Донбаського державного педагогічного університету (Слов'янськ, Донецька область, Україна) nikitina_sdpu@ukr.net

\section{ПРИНЦИПИ ВИКОРИСТАННЯ МУЛЬТИМЕДІЙНИХ НАВЧАЛЬНИХ ЗАСОБІВ У ПРОФЕСІЙНІЙ ІНШОМОВНІЙ ПІДГОТОВЦІ МАЙБУТНІХ ФІЛОЛОГІВ}

Стаття присвячена аналізу принщипів використання мультимедійних засобів навчання у професійній іншомовній підготовці майбутніх філологів. Інтеграчія Украӥни до світового співтовариства вимагає оптимізації системи гуманітарної освіти. Така оптимізація можлива лише за умови впровадження мультимедійних тех- 
нологій у навчальний процес. Процес інтеграиії до європейського освітнього простору стимулює професійний інтерес студентів до вивчення іноземних мов як засобу спілкування, розширення міжнародних відносин, спроб установити нові стандарти відносин між краӥнами Свропейського Союзу. Представлене дослідження є актуальним і натальним, оскільки результати моніторингу навчальних досягнень студентів показали, що рівень їх підготовки з іноземної мови не повністю відповідає вимогам навчальної програми. Тому існує потреба в пошуку нових шляхів організації навчального прочесу, оскільки традиційні форми, методи і засоби не відповідають сучасним тендениіям у достатній мірі та не завжди здатні забезпечити передовий характер професійної освіти. Метою статті є теоретичне обтрунтування змісту принципів використання мультимедійних засобів навчання у професійній іншомовній підготовцчі майбутніх філологів. Такими принципами є: принщип відповідності потребам суспільства; принцип урахування інтересів та професійних потреб студентів-філологів; принции моделювання професійної діяльності майбутніх філологів; принщип комунікативної спрямованості професійної іншомовної підготовки майбутніх філологів; приниип візуалізації; принцип інтегрованого використання мультимедійних засобів навчання; принции позитивної емоційності; принции дотримання ергономічних норм. Упровадження цих принципів у навчальний процес, орієнтований на формування професійної іншомовної компетентності майбутніх філологів, вимагає моделювання і технологізації изього процчесу у вищій иколі.

Ключові слова: мультимедійні засоби навчання, мультимедійні технологї, принцип, професійна іншомовна компетентність, професійна іншомовна підготовка.

The problem setting. Ukraine's integration into the world community makes it necessary to optimize the system of humanitarian education with a focus on the human, the development of his/her spiritual potential. The strategic provisions on the content, forms, peculiarities of education are based on the Constitution of Ukraine, laws of Ukraine "On Education" and "On Higher Education", "National Doctrine of Education of Ukraine in the XXI Century", and are consistent with the requirements of UNESCO, the International Organization of Cooperation and Development of Education, which emphasize the need for humanization of higher education, its technological effectiveness, versatility, and variability. Today, this becomes possible only if modern ideas and educational technologies are introduced, which incorporate the latest domestic and foreign pedagogical discoveries about active learning as a priority principle of the educational process, learning with using information resources, personality-oriented technologies, which are focused on the maximum individualization of learning and create conditions for self-development and self-determination. The process of integration in the European educational space stimulates the professional interest of individuals in learning foreign languages as a means of communication, expanding international relations, trying to establish new standards of relations between the countries of the European Union. The results of the monitoring of students' academic achievements have shown that the level of their foreign language training does not fully meet the requirements of the curriculum. Therefore, there is a need to find new ways to organize the learning process, as traditional forms, methods, and means do not meet modern trends to a sufficient extent and are not always able to ensure the advanced nature of professional education. Because of this, the issue of forming professional foreign language competence (the PFLC) using multimedia teaching aids is particularly relevant and urgent.
The analysis of recent studies and publications. The problem of improving the learning process in institutions of higher education has been the subject of research by domestic and foreign scientists, namely: V. P. Andrushchenko, Yu. K. Babanskyi, I. A. Ziaziun, V. H. Kremen, S. D. Maksymenko, S. O. Sysoieva, and some others.

The need to increase the effectiveness of learning at foreign language faculties is being studied by domestic and foreign scholars in various aspects: the formation of professional competence of future teachers (N. V. Kuzmina, O. E. Lomakina, A. K. Markova, V. A. Slastionin, N. V. Telychko); the professional training of future philologists, foreign language teachers (V. V. Barkasi, O. M. Volchenko, T. V. Zubenko, V. O. Kalinin, S. Yu. Nikolaieva, M. M. Sidun, I. Y. Khalymon); the formation of professional foreign language communicative competence of future translators/interpreters (Ye. V. Dolynskyi, T. Yu. Ternovykh, L. P. Polishchuk, Z. F. Pidruchna); of future journalists (I. M. Chemerys, L. Ye. Nahorniuk).

In the modern educational sphere, the problem of using multimedia technologies is presented with a wide palette of scientific researches: multimedia technologies as a means of increasing the efficiency of training in secondary comprehensive school (H. K. Nazarenko, Yu. N. Yehorova, N. M. Yezhova, N. V. Morze); didactic possibilities of the information technologies (V. P. Bespalko, A. M. Dovhiallo, I. A. Morev, Ye. S. Polat, I. V. Robert); using the multimedia technologies in the professional training of future specialists (T. A. Babenko, V. Yu. Bykov, O. B. Bihych, T. V. Harbuza, L. A. Kartashova, L. I. Morska); the multimedia technologies as a means of teaching and an instrument with the help of which the pedagogical program means are developed (M. A. Bovtenko, M. I. Zhaldak, N. V. Kliemeshova, V. V. Lapinskyi, Ye. I. Mashbyts, P. I. Serdiukov). 
Some theses are devoted to the development of methodological principles of design, creation, and use of multimedia educational programs and complexes for pupils and students (A. M. Hurzhii, S. I. Karp, O. V. Kokhan, H. E. Miram, O. S. Pasichnyk, V. H. Redko). In foreign pedagogical thought the use of multimedia technologies and their didactic potential are studied by P. Brett, M. Meiers, R. Mayer, M. Neo, and K. Neo.

The purpose of the article is to substantiate theoretically the content of the principles of using the multimedia teaching aids in professional foreign language training of future philologists.

The presentation of the material. Studying the problem of formation of the PFLC of future philologists using multimedia technologies provides defining the theoretical bases concerning the organization of this process. The general strategy of teaching foreign languages at the language faculty of an institution of higher education puts forward a requirement for the development of the foreign language communicative competence, which ensures free communication with the help of a foreign language in the professional, scientific, personal and educational spheres. It provides for the practical mastering skills and abilities of speech at a level sufficient for the implementation of foreign language communication in four types of speech activity in typical situations of their professional activity by students. The professional foreign language training of students is its practical organization, taking into account the peculiarities of the activity that the student will perform in the future (Nikolaieva, 1995: 7). In this context, the professional foreign language training of future philologists is considered as an organization of the learning process, which includes a set of topics and situations that allows bringing the educational activities of students-philologists in purpose, form, and means of its implementation to the real conditions of professional communication. The professional sphere of communication includes topics and situations that are somehow related to the professional activities of communicators. It should be noted that the topic of communication is the subject of the image, expression, and discussion. Within the topics of communication, there are situations of communication, which are considered as a set of circumstances in which the implementation of communication takes place (Shcholok, 2005: 143). The foreign language program for language university students identifies the following main thematic blocks - "English-Speaking World and Ukraine", "Modern Life", "Profession". The last block is important for the study presented, as within it future philologists consider the issues directly related to their specialization ("The System of Secondary Education in the UK", "The system of Secondary Education in the United States", "The System of Secondary Education in Ukraine", "University Education", "Exams and Qualifications", "School of the Future", "Profession of a Teacher/Lecturer", etc.) (Project, 2001). In this regard, it is believed that studying these topics focuses on developing practical skills and communication abilities in professional situations (participation in international scientific-practical conferences, writing scientific articles, theses, abstracts, reports, conducting dialogue with foreign colleagues, partners, analyzing and systematizing international sources for research work, planning and conducting classes, communicating with students, colleagues). In addition, the practical orientation of topics and situations provides the educational-cognitive activities of students-philologists a motivated character since studying them provides students with knowledge of the peculiarities of their future profession, possible difficulties they will have to face, consideration of ways to overcome them. This also requires the manifestation of skills to evaluate and regulate one's activities, activates the development of professionally significant qualities, and forms a positive attitude of students towards the future profession of a philologist.

Thus, it can be concluded that studying the thematic block "Profession" involves personal and professional development and self-development of future philologists, which is relevant in achieving the goal of the professional foreign language training of future philologists - the formation of their PFLC.

Implementing the Program involves the achievement by students-philologists in the professional sphere of communication of the level of a competent user for the first foreign language, which corresponds to the level C.2.1 (Mastery Professional) of the scale offered in the Common European Recommendations of proficiency in a foreign language: studying, teaching, assessing (Common European Recommendations, 2003). However, the discrepancy between the level of professional foreign language preparedness of future philologists to the requirements declared in the program determines the search for new ways to improve the learning process. In this regard, the didactic potential of multimedia teaching aids has been investigated. However, it is necessary to note that using any technologies must be consistent with the entire system of teaching the foreign language, must correlate with its goals and principles.

The next point of the study presented is to clarify the issue of the principles of using multimedia teaching aids in the process of the professional foreign language training of future philologists. The scientists argue that the principles of learning are those basic provisions that, in their totality, determine the 
requirements for the training process as a whole and for its components (goals, objectives, methods, means, organizational forms, and the learning process itself). The relevant for the investigation presented is the opinion of S. V. Honcharenko that the principles do not exist separately but form a system of provisions based on which the learning process is carried out. They act in an organic unity, forming a certain concept of the didactic process, which can be represented as a system, the components of which they are (Honcharenko, 2012: 100).

Studying modern pedagogical investigations shows that currently there is no single classification of teaching principles. One of the approaches to defining them is the idea of the basic sciences that there is in the focus of the problem investigated: didactics, linguodidactics, psychology, and teaching methods. Consequently, the system of principles for using multimedia aids in the process of professional foreign language training of future philologists is a set of didactic, linguodidactic, psychological, and methodical principles proper.

In traditional didactics, the so-called classical principles are considered generally accepted, they are the principles of visibility, accessibility, consciousness and activity, systematicity and consistency, endurance, scientific character, connection between theory and practice (Khutorskoi, 2003: 57). At the same time, it is possible to single out the principles (or group of principles) that are the leading ones under specific learning conditions. For example, currently, the priority methodical principle of teaching a foreign language is the principle of communicativeness, which provides a practical orientation of classes, focuses on mastering speech activity in the chosen field of communication. Among psychological principles, researchers prefer the principle of motivation, as mastering professional foreign language communication will be ineffective without taking into account the interests of students and purposeful influence on the motivational sphere of their activities, which determines their behavior (Shchukin, 2006: 148).

Summarizing the above mentioned, it should be noted that the system of principles is open and allows including the new ones and rethinking those that already exist, because they reflect the social needs of people, are changed and improved under the influence of technological progress and science.

The issue of determining the principles of using multimedia aids in teaching foreign languages is the subject of scientific research of Ukrainian and foreign scientists. As a result of the analysis of most of them, the authors have come to the conclusion that the theoretical basis of these classifications is the ideas of the personality-oriented and communicative-activity direction of teaching a foreign language, which have been substantiated in the works of the researchers (I. L. Bim, N. D. Halskova, I. O. Zymnia, H. A. Kytaihorodska, O. M. Lieontiev, S. Yu. Nikolaieva, Yu. I. Passov, V. M. Plakhotnyk, Ye. S. Polat, S. P. Shatilov, etc.). At the same time, as it is known, the general-didactic approach outlining the direction of the whole process of teaching and learning a foreign language, it is recognized the competence approach, the works of educators and methodologists are devoted to (O. B. Bihych, L. Ye. Nahorniuk, S. Yu. Nikolaieva, O. V. Ovcharuk, O. I. Pometun, V. H. Redko, O. Ya. Savchenko, I. V. Sokolova, A. V. Khutorskoi, A. M. Shchukin, etc.). These approaches are relevant for the study presented, so the authors focus on them in determining the principles of using multimedia technologies in the process of professional training of future philologists.

Taking into account the current goals of professional training of students-philologists, as well as the technologies of their implementation, it is appropriate to analyze the list of principles that would contribute to the program requirements and provide opportunities for future philologists using multimedia teaching aids. This is due to the need to determine the theoretical foundations for the organization of the process of professional foreign language training using multimedia teaching aids, focused on personal and professional development and self-development of future philologists. The following principles should be distinguished: 1) the principle of compliance with the needs of society; 2) the principle of taking into account the interests and professional needs of students-philologists; 3 ) the principle of modelling the professional activities of future philologists; 4) the principle of the communicative orientation of professional foreign language training of future philologists; 5) the principle of visualization; 6) the principle of the integrated use of multimedia teaching aids; 7) the principle of positive emotionality; 8 ) the principle of observance of ergonomic norms.

The principle of compliance with the needs of society involves using multimedia aids in accordance with the social needs of society and the goals set by the state for education in general and the subject "Foreign Language" in particular. The purpose of state policy on the development of higher education is to train competent professionals who are able to work effectively and learn throughout life, preserve and increase the values of national culture (National Doctrine, 2002: 4), capable of independent professional activity in an information society, which can significantly improve the quality of life and socio-political stability of the state. Using multimedia aids in the process of professional foreign language training 
of future philologists determines the clearest possible fulfilment of the needs of society. Therefore, the introduction of multimedia technologies in the educational process should promote the mental and intellectual development of students-philologists, increase the level of information culture, ensure their preparedness for professional foreign language communication, and further self-education in foreign philology.

The principle of taking into account the interests and professional needs of students-philologists ensures that the level of language and speech training of students, the peculiarities of perception of information that is diverse in content and form, and the pace of work with educational materials should be taken into account. As the representatives of the personality-oriented approach (I. L. Bim, S. Yu. Nikolaieva, Ye. S. Polat, Z. I. Sliepkan, A. V. Khutorskoi, etc.), students are different in intellectual abilities, type of thinking, pace of knowledge acquisition, which should be taken into account in the organization of education (Sliepkan, 2005: 65). This principle regulates the choice and purpose of implementing multimedia teaching aids, which must be adapted to the individual abilities of students and the level of foreign language preparedness, willingness to work with them (interest, sufficient level of information culture), which will contribute to the development of the individuality of each student-philologist, creating a positive attitude to learning. At the same time, the principle of taking into account the interests and professional needs determines the selection of professionally-oriented topics for communication, creative tasks, projects in the content of multimedia teaching aids that are important for future philologists and, accordingly, stimulate interest in the future profession and new means of mastering the educational material. It should be assumed that compliance with this principle will ensure the motivation of the learning process, stimulate the disclosure of personal potential, promote the professional development and self-development of future philologists.

The principle of modelling the professional activities of future philologists involves taking into account the peculiarities of the future specialty. Under the modelling of professional activities in the educational process, it is understood the identification of typical tasks, their transformation into training and production ones, the choice of forms of organization of the educational process, teaching methods (Honcharenko, 1997: 125). Psychologists emphasize that the leading activity in higher school is the educational-professional one. Such activity most intensively influences personal growth and professional development of students, acquisition of professionally important knowledge, skills, and abilities by them (Podo- liak, 2006: 79). The task of modelling is to establish a correspondence between the requirements for training and the actual amount of professional knowledge, skills, and abilities. The principle of modelling the professional activities of future philologists in the context of our study involves building a process of professional foreign language training as a model of the professional process by involving multimedia teaching aids to create professionally-oriented learning situations to gain by future philologists the necessary professional and personal experience, which is necessary to perform their professional duties, namely: implementing scientific-research work, pedagogical activities in higher school, performing the functions of a translator/interpreter, journalist, literary critic. It should be assumed that using multimedia teaching aids in modeling the professional activities will bring students-philologists closer to the real conditions of future professional activities, and, thus, contribute to the formation of personal and professional experience, stimulate the development of their professionally significant qualities.

The principle of the communicative orientation of professional foreign language training of future philologists provides orientation of the learning process of communication. The implementation of the principle is to bring the process of professional foreign language training of future philologists as close as possible to the conditions of natural communication using multimedia teaching aids. According to this principle, the educational-professional activities of future philologists provide for such an orientation of classes in which the goal of learning (mastering the language as a means of communication), the means to achieve the goal (speech), as well as the means of realizing the content are closely interconnected. This principle regulates the content of multimedia aids used in the process of professional foreign language training of future philologists; assumes that they have communicatively oriented exercises and tasks that are of an activity nature and are focused on the development of four types of speech activity in interconnection; predetermines the use of multimedia aids in interactive teaching methods (role-play, business game, conversation, discussion), which are aimed at the acquisition of communication experience by future philologists; provides for the attraction of multimedia in various forms of work (individual, pair, group), ensuring the mastery by students of the skills and abilities of monological, dialogical and polylogical speech. Considering the said above, it is believed that compliance with this principle will contribute to the formation of philological knowledge and skills in future philologists and the improvement of practical skills, as well as the development of professionally significant qualities. 
The principle of visualization is based on one of the leading principles of didactics and is relevant within the scope of our study. Its relevance is explained by the dialectic of the transition from sensory perception to abstract thinking in the process of cognition (Shchukin, 2006: 152). Modern methodological science involves the intensive use of various types of visualization (static, dynamic), since visualization is considered as the main source of speech skills and abilities (Solovova, 2002). The principle of visualization leads to the quality of illustrative materials in multimedia teaching aids (choice of color, font size, and type, placement on the screen, sound, animation), which affects the aesthetic and emotional perception of students.

The principle of the integrated use of multimedia teaching aids presupposes the unity of all the components of the educational process: objectives, content, methods, organizational forms, and teaching means with the leading role of the learning objectives (Sliepkan, 2005: 28). The opinion of specialists about the need to integrate traditional and new educational technologies, modern information technologies which intensify the educational-cognitive activities of university students. In light of this, the principle of the integrated use of multimedia teaching aids predetermines the special organizational unity, the complexity of the use of traditional (textbooks, teaching guides, handouts, video, and audio materials, periodicals, works of art, TV programs) and multimedia aids of implementing the content to achieve the leading goal - the formation of the studied personality neoplasm. The effectiveness of this process requires the integration of the efforts of the lecturer, who must skillfully and methodically use a variety of means for modeling professionally-oriented learning activities, and students, who must be psychologically and practically prepared to use multimedia in teaching.

The principle of positive emotionality determines the formation in students-philologists of interest in professional knowledge, mastery of skills and abilities of professional foreign language communication, as well as a positive attitude to the future profession of a philologist. The emotional activity is connected with the question - is it interesting or not for students to learn foreign languages? A positive emotional attitude towards the subject plays a big role in achieving success. Negative emotions block students' activity (Psychology, 2001). According to S. Zaniuk, the most important thing that will lead to the development of the needs or motives of a certain activity is a combination of positive emotions, satisfaction with a certain activity (Zaniuk, 2001: 90). Thus, one of the most important factors in forming the individual's need for professional self-realization is the experience of positive emotions during educa- tional activities. A student can get positive emotions, firstly, from the learning process itself, the realization of his/her own potential, the disclosure of his/ her abilities; secondly, a human gets pleasure from the result of his/her activities; thirdly, positive emotions are caused by the high appreciation of the process and results of learning activities by other people. According to the outlined problem, this principle focuses on the use of interesting didactically and methodically appropriate multimedia teaching aids that evoke positive emotions in future philologists, provide as many opportunities for creativity as possible, create a situation of success, which will increase satisfaction with the subject "Foreign Language" and the formation of a positive attitude to the future profession and multimedia learning means as such.

The principle of observance of ergonomic norms determines the controlled use of multimedia aids during training, taking into account the problem of the impact that the computer has on the user's health. The authors of modern publications raise the issue of the negative impact of this technical means of learning on the eyesight, nervous system of students. Scientists point out that prolonged computer use can cause fatigue, back pain, neck pain, etc. In this regard, specialists are unanimous that it is necessary to comply with medical ergonomic requirements that determine the safe and efficient use of this technical means, namely: limited work with a computer, variation of different types of work for students in classes, integrated use of traditional and multimedia teaching aids that attract various organs of perception, the introduction of interactive forms of work in the process of professional foreign language training of future philologists. Strict adherence to specially designed rules and preventive measures can reduce the negative impact of computers on the health of students.

Conclusions. Introducing multimedia technologies in the process of professional foreign language training of students-philologists requires compliance with the principles of using multimedia teaching aids in the process of professional foreign language training of future philologists, due to the trends in the development of professional education and teaching foreign languages (the principle of compliance with the needs of society; the principle of taking into account the interests and professional needs of students-philologists; the principle of modeling the professional activities of future philologists; the principle of the communicative orientation of professional foreign language training of future philologists; the principle of visualization; the principle of the integrated use of multimedia teaching aids; the principle of positive emotionality; the principle of observance of ergonomic norms). These princi- 
ples serve as a theoretical basis for the organization of educational-cognitive activities of future philologists with the help of multimedia technologies. At the same time, the effectiveness of using multimedia aids in the educational process, which ensures the formation of professional foreign language com- petence of future philologists, is subject to specific didactic conditions. Introducing these principles in the educational process, which is focused on the formation of professional foreign language competence of future philologists, requires modeling and technologicalization of this process in higher school.

\section{BIBLIOGRAPHY}

1. Гончаренко С. У. Український педагогічний словник. Київ: Либідь, 1997. 376 с.

2. Гончаренко С. У. Педагогічні закони, закономірності, принципи. Сучасне тлумачення. Рівне: Волинські береги, 2012. $192 \mathrm{c}$.

3. Загальноєвропейські Рекомендації з мовної освіти: вивчення, викладання, оцінювання. Наук. ред. укр. вид. доктор пед. наук, проф. С. Ю. Ніколаєва. Київ: Ленвіт, 2003. 273 с.

4. Занюк С. Психология мотивации. Киев: Эльга-Н; Ника-Центр, 2001. 352 с.

5. Національна доктрина розвитку освіти України у XXI столітті. Київ: Освіта, 2002. 24 с.

6. Ніколаєва С. Ю. Концепція підготовки вчителя іноземної мови. Іноземні мови. 1995. № 3-4. С. 5-10.

7. Подоляк Л. Г.Психологія вищоїшколи: навч. пос. для магістрантів і аспірантів. Київ: ТОВ «Філ-студія», 2006.320 с.

8. Програма 3 англійської мови для університетів/інститутів (п'ятирічний курс навчання): Проект. Кол. авт.: С. Ю. Ніколаєва, М. І. Соловей (керівники), Ю. В. Головач та ін. Київ. держ. лінгв. ун-т та ін., Британська Рада, Міністерство освіти і науки України. Вінниця: Видавництво «Нова книга», 2001. 247 с.

9. Психологія. Ред. Ю. Л. Трофімов, В. В. Рибалка, П. А. Гончарук та ін. Підр. для студ. ВНЗ. Вид. 3-е, стереотипне. Київ: Либідь, 2001. 558 с.

10. Слєпкань 3. І. Наукові засади педагогічного процесу у вищій школі: навч. пос. Київ: Вища школа, 2005. 239 с.

11. Соловова Э. Н. Методика обучения иностранным языкам: базовый курс лекций: пос. для студ. пед. вузов и учит. Москва: Просвещение, 2002. 239 с.

12. Хуторской А. В. Ключевые компетенции как компонент личностно-ориентированной парадигмы образования. Народное образование. 2003. № 2. С. 58-64.

13. Щолок О. Б. Педагогічний потенціал інформаційно-навчального середовища. Збірник наукових праць Уманського державного педагогічного університету ім. П. Тичини. Спец. Випуск. Київ: Міленіум, 2005. С. $245-249$.

14. Щукин А. Н. Обучение иностранным языкам: Теория и практика: учебн. пос. для препод. и студ. 2-е изд., испр. и доп. Москва: Филоматис, 2006. 480 с.

\section{REFERENCES}

1. Honcharenko S. U. (1997). Ukrainskyi pedahohichnyi slovnyk [Ukrainian pedagogical dictionary]. Kyiv: Lybid [in Ukrainian].

2. Honcharenko S. U. (2012). Pedahohichni zakony, zakonomirnosti, pryntsypy. Suchasne tlumachennia [Pedagogical laws, patterns, principles. Modern interpretation]. Rivne: Volynski berehy [in Ukrainian].

3. Zahalnoievropeiski Rekomendatsii z movnoi osvity: vyvchennia, vykladannia, otsiniuvannia [Common European Recommendations on Language Education: Learning, Teaching, Assessment]. (2003). S. Yu. Nikolaieva (Ed.). Kyiv: Lenvit [in Ukrainian].

4. Zaniuk S. (2001). Psikhologiia motivatsii [Psychology of motivation]. Kiev: Elga-N; Nika-Tcentr [in Russian].

5. Natsionalna doktryna rozvytku osvity Ukrainy u XXI stolitti [National Doctrine of Development of Education of Ukraine in the $21^{\text {st }}$ Century]. (2002). Kyiv: Osvita [in Ukrainian].

6. Nikolaieva S. Yu. (1995). Kontseptsiia pidhotovky vchytelia inozemnoi movy [Concept of training of a foreign language teacher]. Inozemni movy - Foreign Languages, 3-4, 5-10 [in Ukrainian].

7. Podoliak L. H. (2006). Psykholohiia vyshchoi shkoly: navch. pos. dlia mahistrantiv i aspirantiv [Psychology of higher school: teaching manual for masters and post-graduates]. Kyiv: TOV «Fil-studiia» [in Ukrainian].

8. Prohrama $\mathrm{z}$ anhliiskoi movy dlia universytetiv/instytutiv (piatyrichnyi kurs navchannia): Proekt [English language program for universities/institutes (five-year course): Project]. (2001). Kyiv. derzh. linhv. un-t ta in., Brytanska Rada, Ministerstvo osvity i nauky Ukrainy. Vinnytsia: Vydavnytstvo «Nova knyha» [in Ukrainian].

9. Psikhologiia [Psychology]. (2001). Iu. L. Trofimov, V. V. Ribalka, P. A. Goncharuk ta in. (Eds.). Kiïv: Libid [in Russian].

10. Sliepkan Z. I. (2005). Naukovi zasady pedahohichnoho protsesu u vyshchii shkoli: navch. pos. [Scientific foundations of the pedagogical process in higher school: teaching manual]. Kyiv: Vyshcha shkola [in Ukrainian].

11. Solovova E. N. (2002). Metodika obucheniia inostrannym iazykam: bazovyi kurs lektcii: pos. dlia stud. ped. vuzov i uchit. [Teaching methods of foreign languages: basic course of lectures: manual for students of universities and teachers]. Moskva: Prosveshchenie [in Russian].

12. Khutorskoi A. B. (2003). Kliuchevye kompetentcii kak komponent lichnostno- orientirovannoi paradigmy obrazovaniia [Key competeces as a component of personality-oriented paradigm of education]. Narodnoe obrazovanie - Folk Education, 2, 58-64 [in Russian].

13. Shcholok O. B. (2005). Pedahohichnyi potentsial informatsiino-navchalnoho seredovyshcha [Pedagogical potential of information and educational environment]. Zbirnyk naukovykh prats Umanskoho derzhavnoho pedahohichnoho universytetu im. P. Tychyny. Spets. Vypusk-Collection of Scientific Works of P. Tychyna Uman State Pedagogical University. Special Issue, 245-249. Kyiv: Milenium [in Ukrainian].

14. Shchukin A. N. (2006). Obuchenie inostrannym iazykam: Teoriia i praktika: uchebn. pos. dlia prepod. i stud. [Teaching foreign languages: Theory and practice: teaching manual for lecturers and students]. Moskva: Filomatis [in Russian]. 